\title{
Phenolic compounds and vitamins in wild and cultivated apricot (Prunus armeniaca L.) fruits grown in irrigated and dry farming conditions
}

\author{
Tuncay Kan ${ }^{1}$, Muttalip Gundogdu², Sezai Ercisli ${ }^{3}$ Ferhad Muradoglư ${ }^{4}$ Ferit Celik ${ }^{4}$, Mustafa Kenan Gecer ${ }^{5}$, \\ Ossama Kodad ${ }^{6 *}$ and Muhammad Zia-UI-Haq ${ }^{7}$
}

\begin{abstract}
Background: Turkey is the main apricot producer in the world and apricots have been produced under both dry and irrigated conditions in the country. In this study, phenolic compounds and vitamins in fruits of one wild (Zerdali) and three main apricot cultivars ('Cataloglu', 'Hacihaliloglu' and 'Kabaasi') grown in both dry and irrigated conditions in Malatya provinces in Turkey were investigated.

Results: The findings indicated that higher content of phenolic compounds and vitamins was found in apricot fruits grown in irrigated conditions. Among the cultivars, 'Cataloglu' had the highest rutin contents both in irrigated and dry farming conditions as $2855 \mu \mathrm{g}$ in irrigated and $6952 \mu \mathrm{g}$ per $100 \mathrm{~g}$ dried weight base in dry conditions and the highest chlorogenic acid content in irrigated and dry farming conditions were measured in fruits of 'Hacıhaliloglu' cultivar as $7542 \mu \mathrm{g}$ and $15251 \mu \mathrm{g}$ per $100 \mathrm{~g}$ dried weight base. Vitamin C contents in homogenates of fruit flesh and skin was found to be higher than $\beta$-caroten, retinol, vitamin $\mathrm{E}$ and lycopen contents in apricot fruits both in irrigated and dry farming conditions.

Conclusion: The results suggested that apricot fruits grown in both dry and irrigated conditions had high health benefits phytochemicals and phytochemical content varied among cultivars and irrigation conditions as well. However, more detailed biological and pharmacological studies are needed for the demonstration and clarification of health benefits of apricot fruits.
\end{abstract}

Keywords: Apricot, Phytochemicals, Ripening, Irrigation, HPLC

\section{Background}

Turkey is a leading producer of both fresh and dried apricots (Prunus armeniaca L.) in the world for a long time and the country is accepted second homeland of apricot after China [1]. Despite wide cultivation in many parts of the world, Malatya province located in eastern Turkey is particularly important for apricot production and processing due to its favourable climatic and geographical conditions and the province called center of apricot in the World.

Apricot fruits are rich in minerals, organic acids, phenolic compounds and carbohydrates [2-4]. The fruits

\footnotetext{
* Correspondence: osama.kodad@yahoo.es

${ }^{6}$ Departement of Pomology, National School of Agriculture, Meknes, Morocco

Full list of author information is available at the end of the article
}

can be consumed fresh or dried but most of the globally produced apricots are consumed as fresh. Moreover apricot kernels are utilized as raw materials in snack, pharmaceutical and in cosmetic industries [5,6].

Phenolic compounds exist in fruits and vegetables at varying levels and they have a determinant role in taste formation and they contribute to astringency and bitterness in horticultural crops [7-9]. Anthocyanins are phenolic compounds that are responsible for colour formation of fruits and vegetables. Phenolic compounds have an important role in fruit juice processing industry since they increase the turbidity and sedimentation of drinks such as fruit juices and wines [10]. Phenolics, in particular, are thought to act as antioxidant, anti-carcinogenic, anti-microbial, anti-allergic, anti-mutagenic and anti-inflammatory, as well as reduce cardiovascular diseases [11]. 
The apricot fruits belongs to different cultivars contain different levels of polyphenols as summarized by Macheix et al. [12]. Chlorogenic acid (5-caffeoylquinic acid) is the dominant phenolic compound in apricots. The other phenolic compounds determined in apricots are neochlorogenic acid, caffeic acid, p-coumaric acid, ferulic acid and their esters. (+)-Catechin and (-)-epicatechin are also determined in apricot fruits and their products [13-15]. Flavonols in apricots occur mostly as glucosides and rutinosides of quercetin and of kaempferol, however, quercetin 3-rutinoside (rutin) predominates $[13,16]$. Apricot fruits contain different levels of phytochemicals such as vitamins, carotenoids and polyphenols, which are the determinants of taste, colour and nutritive values of the fruits $[17,18]$.

The study aimed to investigate the phenolic compounds and vitamins in fruits of wild and cultivated apricots grown in dry and irrigated farming conditions. Rapidly increasing demand on world water resources brings pressure on use of irrigation water as well as use of drinking water. In these circumstances, the study is particularly important as its aims to investigate the effects of dry farming on some important human health related biochemical characteristics of apricots.

\section{Results and discussion Phenolic profile}

The study reports the effects of irrigation practices on human health related biochemical contents of cultivated (cvs. 'Cataloglu', 'Hacihaliloglu', 'Kabaasi)' and wild (Zerdali) apricot genotype. The findings in general indicated remarkably lower contents of phenolic compounds in the fruits of apricots grown in irrigated conditions compared to their dry farmed counterparts.

In terms of phenolic compound profile, chlorogenic acid and rutin were found to be the predominant phenolics (Table 1). The highest epicatechin and gallic acid content in both irrigated and dry farming conditions was recorded in fruits of 'Cataloglu' apricot cultivar as 424 and $1654 \mu \mathrm{g}$; 130 and $282 \mu \mathrm{g}$ per $100 \mathrm{~g}$ dry fruit base, respectively (Table 1). Chlorogenic acid contents of Hacihaliloglu apricot were measured as $7543 \mu \mathrm{g}$ per $100 \mathrm{~g}$ dry fruit in irrigated farming conditions and as $15252 \mu \mathrm{g}$ per $100 \mathrm{~g}$ in dry farming conditions (Table 1). Contents of $p$-coumaric acid, ferulic acid, procyanidin (B1, B2, B3), catechin, rutin, caffeic acid, epigallocatechin and 3-B-Q-D were generally found to be higher in dry farming conditions (Table 1). The analysis of phenolic compounds indicated that fruits of 'Cataloglu' apricot cultivar had the highest rutin, epicatechin, gallic acid, epigalloketechin and 3-B-Q-D; Hacihaliloglu apricot fruits had the highest chlorogenic acid and procyanidin B2 (dry-farming conditions), Kabaasi apricot fruits had the highest p-coumaric acid, ferulic acid (dry-farming conditions), procyanidin $\mathrm{B} 1$, catechin, procyanidin $\mathrm{B} 2$ (irrigated) and caffeic acid and wild apricot (Zerdali) fruits had the highest contents of ferulic (irrigated), 3-B-Q-D (dry-farming) and procyanidin contents (Table 1). In the study of Dragovic-Uzelac et al. [19], gallic acid contents of 'Keckemetska' apricots grown in Baranja region in Croatia were recorded as 3.47, 2.35 and $2.43 \mathrm{mg}$ per $\mathrm{kg}$ in immature, semi-mature and full mature stages, respectively. Those authors also reported chlorogenic acid contents in the three maturity stages in apricot as 18.87, 16.05 and $14.69 \mathrm{mg}$ per $\mathrm{kg}$. They also investigated the changes in caffeic acid, p-coumaric acid, ferulic acid, catechin, epicatechin and procyanidin $(\mathrm{B} 1, \mathrm{~B} 2, \mathrm{~B} 3)$ contents according to maturity stages. Sultana et al. [20], measured $p$-coumaric acid content in dry apricot fruit and reported as $23.6 \mathrm{mg}$ per $\mathrm{kg}$, ferulic acid content as $13.9 \mathrm{mg}$ per $\mathrm{kg}$, caffeic acid content as $6.70 \mathrm{mg}$ per $\mathrm{kg}$ and gallic acid content as $4.54 \mathrm{mg}$ per $\mathrm{kg}$. Similar studies have been conducted also by other researchers [13,21]. While some of the findings of this study conducted in Malatya region are in accord with the findings of other researchers, some findings are in discord with those findings. These differences may be attributed to the differing characteristics of cultivars used in studies as well as differences in crop procedures, climatic conditions and geographical factors. Flavonoid glycosides, a group of phenolic compounds, are light yellow in colour and found in almost all plants. As their synthesis in plants is stimulated by sunlight, they are largely found in fruit skins. Flavonoid glycosides are major determinants of colour formation, hence, climatic factors such as temperature and light are considered to have an important role [10].

\section{Vitamin content}

The effects of irrigated and dry farming conditions on $\beta$-carotene, retinol, vitamin $E$, lycopen and vitamin $C$ contents in fruits of examined apricots were investigated. The highest $\beta$-carotene contents in both irrigated and dry farming conditions were measured in fruits of 'Hacihaliloglu' apricot cultivar as $1949 \mu \mathrm{g}$ per $100 \mathrm{~g}$ and $3275 \mu \mathrm{g}$ per $100 \mathrm{~g}$ (Table 2). The highest vitamin $\mathrm{C}$ content in both irrigated and dry farming conditions was measured in fruits of 'Cataloglu' cultivar as $20246 \mu \mathrm{g}$ and $60656 \mu$ g per $100 \mathrm{~g}$ dry weight base (Table 2). The highest retinol content in irrigated farming conditions was measured in fruits of 'Hacihaliloglu' cultivar as $21.15 \mu \mathrm{g}$ per $100 \mathrm{~g}$ dry weight base and the highest retinol content in dry farming conditions was measured in fruits of 'Cataloglu' apricot cultivar as $28.10 \mu \mathrm{g}$ per $100 \mathrm{~g}$. In general, the ranking of vitamin content in the examined apricots was determined as Vitamin $\mathrm{C}>$ Beta caroten $>$ Lycopen $>$ Vitamin E $>$ Retinol (Table 2). Dragovic-Uzelac et al. [19] conducted a study on 'Keckemetska Ruza', 'Madjarska Najbolja' and 'Velika Rana' apricot cultivars grown in 


\begin{tabular}{|c|c|c|c|c|c|}
\hline \multirow{2}{*}{$\begin{array}{l}\text { Phenolic } \\
\text { compounds }\end{array}$} & \multirow[t]{2}{*}{ İrigated/Dry } & \multicolumn{4}{|l|}{ Cultivars } \\
\hline & & Cataloglu & Hacıhaliloglu & Kabaasi & Zerdali \\
\hline \multirow[t]{2}{*}{ Rutin } & Irrigated & $2855.10 \pm 0.14^{\mathrm{a}^{*}}$ & $1550.25 \pm 0.17^{d}$ & $2656.10 \pm 0.19^{b}$ & $1760.90 \pm 0.26^{c}$ \\
\hline & Dry & $6952.95 \pm 0.76^{a}$ & $3946.90 \pm 0.29^{d}$ & $6642.70 \pm 0.59^{b}$ & $4159.60 \pm 0.32^{c}$ \\
\hline \multirow[t]{2}{*}{ Epicatechin } & Irrigated & $423.55 \pm 0.11^{a}$ & $40.40 \pm 0.20^{d}$ & $310.70 \pm 0.60^{c}$ & $365.40 \pm 0.20^{b}$ \\
\hline & Dry & $1653.60 \pm 0.98^{\mathrm{a}}$ & $156.30 \pm 0.11^{d}$ & $657.65 \pm 0.33^{c}$ & $871.85 \pm 0.24^{b}$ \\
\hline \multirow[t]{2}{*}{ P-coumaric } & Irrigated & $5.40 \pm 0.30^{b}$ & $7.50 \pm 0.40^{b}$ & $21.55 \pm 0.11^{a}$ & $5.30 \pm 0.30^{b}$ \\
\hline & Dry & $15.50 \pm 0.30^{c}$ & $32.60 \pm 0.11^{b}$ & $44.00 \pm 0.21^{a}$ & $13.05 \pm 0.15^{c}$ \\
\hline \multirow[t]{2}{*}{ Ferulic } & Irrigated & $431.25 \pm 0.12^{c}$ & $372.75 \pm 0.67^{d}$ & $884.75 \pm 0.10^{b}$ & $1136.90 \pm 0.16^{\mathrm{a}}$ \\
\hline & Dry & $1057.05 \pm 0.28^{c}$ & $1044.05 \pm 0.20^{c}$ & $2440.75 \pm 0.25^{a}$ & $1446.35 \pm 0.95^{b}$ \\
\hline \multirow[t]{2}{*}{ Gallic acid } & Irrigated & $129.75 \pm 0.81^{a}$ & $87.35 \pm 0.36^{b}$ & $35.40 \pm 0.13^{c}$ & $49.30 \pm 0.40^{c}$ \\
\hline & Dry & $282.30 \pm 0.60^{a}$ & $216.40 \pm 0.51^{b}$ & $75.15 \pm 0.12^{d}$ & $108.95 \pm 0.56^{c}$ \\
\hline \multirow[t]{2}{*}{ Procyanidin B1 } & Irrigated & $46.90 \pm 0.23^{d}$ & $72.55 \pm 0.43^{b c}$ & $82.85 \pm 0.19^{a}$ & $63.80 \pm 0.13^{c}$ \\
\hline & Dry & $112.10 \pm 0.35^{c}$ & $157.30 \pm 0.76^{b}$ & $236.15 \pm 0.18^{a}$ & $77.45 \pm 0.21^{c}$ \\
\hline \multirow[t]{2}{*}{ Catechin } & Irrigated & $1361.95 \pm 0.37^{c}$ & $1560.85 \pm 0.31^{b}$ & $2140.60 \pm 0.77^{\mathrm{a}}$ & $1067.65 \pm 0.14^{d}$ \\
\hline & Dry & $2746.20 \pm 0.11^{c}$ & $3580.30 \pm 0.17^{b}$ & $5124.95 \pm 0.21^{a}$ & $2210.25 \pm 0.21^{d}$ \\
\hline \multirow[t]{2}{*}{ Procyanidin B2 } & Irrigated & $654.20 \pm 0.19^{d}$ & $7140.50 \pm 0.28^{b}$ & $7792.70 \pm 0.40^{a}$ & $6740.40 \pm 0.16^{c}$ \\
\hline & Dry & $1552.40 \pm 0.32^{d}$ & $19534.20 \pm 0.97^{\mathrm{a}}$ & $16563.65 \pm 0.47^{b}$ & $15405.55 \pm 0.15^{c}$ \\
\hline \multirow[t]{2}{*}{ Caffeic acid } & Irrigated & $62.85 \pm 0.25^{d}$ & $187.10 \pm 0.82^{c}$ & $359.35 \pm 0.13^{a}$ & $276.95 \pm 0.19^{b}$ \\
\hline & Dry & $173.95 \pm 0.16^{c}$ & $646.80 \pm 0.31^{b}$ & $845.20 \pm 0.23^{a}$ & $638.00 \pm 0.16^{b}$ \\
\hline \multirow[t]{2}{*}{ Epigallocatechin } & Irrigated & $229.25 \pm 0.73^{a}$ & $34.41 \pm 0.23^{c}$ & $52.80 \pm 0.19^{b}$ & $64.05 \pm 0.15^{b}$ \\
\hline & Dry & $557.55 \pm 0.22^{a}$ & $96.60 \pm 0.31^{b}$ & $134.00 \pm 0.19^{b}$ & $141.60 \pm 0.59^{b}$ \\
\hline \multirow[t]{2}{*}{ 3-B-Q-D } & Irrigated & $271.95 \pm 0.14^{\mathrm{a}}$ & $29.85 \pm 0.11^{c}$ & $26.60 \pm 0.10^{c}$ & $192.70 \pm 0.44^{b}$ \\
\hline & Dry & $446.80 \pm 0.28^{a}$ & $106.45 \pm 0.46^{b}$ & $65.20 \pm 0.33^{b}$ & $405.35 \pm 0.45^{a}$ \\
\hline \multirow[t]{2}{*}{ Procyanidin B3 } & Irrigated & $561.00 \pm 0.61^{c}$ & $729.30 \pm 0.78^{b}$ & $727.15 \pm 0.16^{b}$ & $1641.20 \pm 0.13^{\mathrm{a}}$ \\
\hline & Dry & $2129.75 \pm 0.15^{b}$ & $1652.40 \pm 0.13^{c}$ & $1657.85 \pm 0.35^{c}$ & $2960.95 \pm 0.27^{\mathrm{a}}$ \\
\hline \multirow[t]{2}{*}{ Chlorogenic acid } & Irrigated & $3648.65 \pm 0.23^{b}$ & $7542.75 \pm 0.58^{a}$ & $585.00 \pm 0.10^{d}$ & $1061.80 \pm 0.23^{c}$ \\
\hline & Dry & $6551.15 \pm 0.65^{b}$ & $15251.50 \pm 0.15^{a}$ & $1345.95 \pm 0.13^{d}$ & $2634.50 \pm 0.30^{c}$ \\
\hline
\end{tabular}

*Different letters in lines indicate significantly different values at $p \leq 0.05$.

Neretva valley and they determined $\beta$-caroten contents of these apricot fruits in ripeness stage as 796,1375 , and $948 \mu \mathrm{g}$ per $100 \mathrm{~g}$, respectively. Rigal et al. [22] measured the lycopene contents in control apricots and dry apricots respectively as $3.2 \mu \mathrm{g}$ and $3.1 \mu \mathrm{g}$ per g. Akin et al. [23] determined $\beta$-carotene contents as $8.88 \mathrm{mg}$ per $100 \mathrm{~g}$ in fruits of 'Hacihaliloglu', $21.59 \mathrm{mg}$ per $100 \mathrm{~g}$ in fruits of cv. 'Tokaloglu' and $26.18 \mathrm{mg}$ per $100 \mathrm{~g}$ in fruits of cv. 'Kabaasi' apricots, respectively. Same researchers measured vitamin $\mathrm{C}$ contents as 37.7, 41.6 and $27.9 \mathrm{mg}$ per $100 \mathrm{~g}$ in fruits of 'Hachaliloglu', 'Kabaasi' and 'Cataloglu' apricot cultivars, respectively. The findings of this study are partially in accord with the findings of other researchers and comparatively higher and lower findings are also observed in this study. Vitamin $\mathrm{C}$ is highly affected by factors such as temperature, light etc. and degrades fastly [10]. Therefore, the differences in vitamin contents of examined cultivars are attributed to cultivar characteristics, applied crop procedures and environmental factors.

\section{Conclusion}

Turkey is the world's leading apricot producer and Malatya province is the main apricot growing center in Turkey. The findings of the study indicated that higher contents of phenolic compounds and vitamins are found in fruits grown dry-farming conditions compared to their irrigated counterparts. Phenolic compounds may cause some problems in fruit juice processing industry as they increase turbidity. Hence, irrigated farming conditions may be advantageous in this respect as they result lower contents of phenolics in cultivars. Phenolic compounds and vitamins are important for human health due to their antioxidant properties. Dry-farming conditions are more advantageous in this sense as they result higher contents of phenolics and 


\begin{tabular}{|c|c|c|c|c|c|}
\hline \multirow{2}{*}{$\begin{array}{l}\text { Vitamin } \\
\text { compounds }\end{array}$} & \multirow[t]{2}{*}{ İrigated/Dry } & \multicolumn{4}{|l|}{ Cultivars } \\
\hline & & Cataloglu & Hacıhaliloglu & Kabaasi & Zerdali \\
\hline \multirow[t]{2}{*}{ Betacaroten } & Irrigated & $1150.85 \pm 0.85^{b^{*}}$ & $1949.25 \pm 0.28^{\mathrm{a}}$ & $1176.55 \pm 0.21^{b}$ & $532.60 \pm 0.39^{c}$ \\
\hline & Dry & $1567.80 \pm 0.17^{c}$ & $3274.85 \pm 0.20^{\mathrm{a}}$ & $2675.75 \pm 0.17^{b}$ & $1338.90 \pm 0.16^{d}$ \\
\hline \multirow[t]{2}{*}{ Retinol } & Irrigated & $18.15 \pm 0.55^{b}$ & $21.15 \pm 0.35^{\mathrm{a}}$ & $13.10 \pm 0.70^{c}$ & $10.95 \pm 0.13^{d}$ \\
\hline & Dry & $28.10 \pm 0.50^{\mathrm{a}}$ & $23.95 \pm 0.35^{b}$ & $21.35 \pm 0.45^{c}$ & $21.95 \pm 0.45^{c}$ \\
\hline \multirow[t]{2}{*}{ Vitamin E } & Irrigated & $37.60 \pm 0.40^{\mathrm{a}}$ & $38.30 \pm 0.35^{a}$ & $27.70 \pm 0.80^{b}$ & $27.80 \pm 0.80^{b}$ \\
\hline & Dry & $84.25 \pm 0.75^{a}$ & $85.10 \pm 0.90^{\mathrm{a}}$ & $61.90 \pm 0.16^{b}$ & $62.40 \pm 0.13^{b}$ \\
\hline \multirow[t]{2}{*}{ Lycopen } & Irrigated & $57.85 \pm 0.94^{b}$ & $71.05 \pm 0.45^{\mathrm{a}}$ & $47.80 \pm 0.20^{c}$ & $66.10 \pm 0.19^{a}$ \\
\hline & Dry & $283.60 \pm 0.89^{a}$ & $186.30 \pm 0.60^{c}$ & $246.55 \pm 0.48^{b}$ & $154.95 \pm 0.80^{d}$ \\
\hline \multirow[t]{2}{*}{ Vitamin C } & Irrigated & $20245.95 \pm 0.41^{a}$ & $7341.05 \pm 0.13^{d}$ & $11547.55 \pm 0.36^{b}$ & $8732.55 \pm 0.41^{c}$ \\
\hline & Dry & $60655.85 \pm 0.41^{a}$ & $13549.35 \pm 0.28^{d}$ & $18660.90 \pm 0.82^{c}$ & $26148.20 \pm 0.37^{b}$ \\
\hline
\end{tabular}

*Different letters in lines indicate significantly different values at $p \leq 0.05$.

vitamins in cultivars. Many studies have been conducted on biochemical contents of apricot fruits. Nevertheless, there is limited research investigating the effect of irrigation on biochemical contents of apricots. The study will contribute to literature in this regard and is thought to be a valuable reference for the forthcoming studies.

\section{Methods}

\section{Plant material}

In the study 3 main commercial apricot cultivars ('Cataloglu', 'Hacihaliloglu' and 'Kabaasi') and 1 wild apricot (Zerdali) genotype both grown in same dry and irrigated farming orchards were used. The trees of cultivars were grafted on seedlings of wild apricots. However wild apricot (Zerdali) was ungrafted that grown on their roots. All trees were 11 years old and found 1050 meter a.s.l. with $38^{\circ} 49^{\prime} \mathrm{N}, 37^{\circ} 56^{\prime} \mathrm{E}$ position. The study was conducted in Hekimhan district belongs to Malatya province which is the main apricot growing center in Turkey with its convenient climatic and geographic features. All cultivars and wild material were planted at $5 \times 4 \mathrm{~m}$ row spacing and intra-row spacing in single crop orchards. Drip irrigation with 15 days intervals was employed for irrigated farming conditions. In dry farming conditions, no irrigation was performed and the examined cultivars only utilized rain water. A total 50 fruits of cultivars and wild material were harvested at commercial maturity period (fully orange-ripe stage) and quickly transferred to the laboratory. Then fruits were cut into small pieces, frozen in liquid nitrogen and stored at $-80^{\circ} \mathrm{C}$ for subsequent analysis.

\section{Extraction and determination of phenolic acids and flavonoids}

The polyphenols in examined samples were extracted using a procedure described by Bengoecha et al. [24] Each apricot fruit puree $(50 \mathrm{~g})$ was mixed with $50 \mathrm{~mL}$
methanol/HCl $(100: 1, \mathrm{v} / \mathrm{v})$ which contained $2 \% t \mathrm{BHQ}$, in inert atmosphere $(\mathrm{N})$ during $14 \mathrm{~h}$ at $35^{\circ} \mathrm{C}$ in dark. The extract was then centrifuged at $5000 \mathrm{rpm} 15 \mathrm{~min}$. Supernatant was evaporated to dryness under reduced pressure $\left(35-40^{\circ} \mathrm{C}\right)$. The residue was dissolved in $25 \mathrm{~mL}$ of water/ethanol $(80: 20, \mathrm{v} / \mathrm{v})$ and extracted four times with $25 \mathrm{~mL}$ of ethyl acetate. The organic fractions were combined, dried for 30-45 min with anhydrous sodium sulphate, filtered through the Whatman No. 40 filter paper (Whatman International Ltd., Kent, England) and evaporated to dryness under vacuum $\left(35-40^{\circ} \mathrm{C}\right)$. The residue was dissolved in $1 \mathrm{~mL}$ of methanol/water $(50: 50, \mathrm{v} / \mathrm{v})$ and filtered through $0.45 \mu \mathrm{m}$ filter (Nylon Membranes, Supelco Inc., Bellefonte, PA, USA) before injected $(20 \mu \mathrm{L})$ into the HPLC apparatus. Samples were extracted in triplicate.

Extractions were performed on a DionexASE 200 (Dionex Corp., Sunnyvale, CA, USA) system. Percentages of methanol and water in the solvent, temperature, pressure and static extraction time were the parameters under study. The pre-set default conditions were as follows: pre-heating period, $5 \mathrm{~min}$; solvent flush volume, $60 \%$ of the extraction cell volume; number of extraction cycles, 3; purge, $90 \mathrm{~s}$ using pressurized nitrogen (99.995\% of purity, 150 p.s.i.); and collection, in $60 \mathrm{ml}$ glass vials with teflon coated rubber caps (I-CHEM,New Castle, DE, USA). The solvent used was previously degassed in order to avoid the oxidation of the analytes under the operating conditions. Optimum extraction conditions were determined as $1500 \mathrm{psi}$ pressure, $40^{\circ} \mathrm{C}$ temperatures and an hour application time in PLE system. PEE (1 g) was mixed in gradient conditions with (methanol/water/hydrochloric acid; 75:20:5) which contained 2\% tBHQ in 11-or 22-ml stainless steelextraction cells. Then, each one was filtered through a $0.45 \mu \mathrm{m}$ nylon membrane (Lida, Kenosha, WI, USA) and transferred to a 
$50 \mathrm{ml}$ volumetric flask. Solvents were evaporated to dryness in a Turbovap LV Evaporator (Zymark, Hopkinton, MA, USA) provided with a nitrogen stream in a water bath at $40^{\circ} \mathrm{C}$. The residue was reconstituted in $(2 \mathrm{ml})$ methanolwater-aqueous (50:50, v/v) and which was brought up to its volume with methanol-water filtered through a $0.45 \mu \mathrm{m}$ PTFE filters (Waters, Milford, CA, USA) prior to injection into the HPLC system.

Polyphenol analysis were performed on a Agilent Series 1100 liquid chromatography, equipped with a vacuum degasser, a quaternary pump and a Agilent 1100, G 1315B DAD detector, connected to a HPChemStation software. A reversed-phase ACE 5 C18A11608 $(250 \times 4.6 \mathrm{~mm}, 4 \mu \mathrm{m})$ column was used. The content of solvents and used gradient elution conditions were previously described by Dragovic-Uzelac et al. [15]. For gradient elution mobile phase a contained 3\% acetic acid in water; solution B contained a mixture of 3\% acetic acid, $25 \%$ acetonitrile and $72 \%$ water. The following gradient was used: $0-40 \mathrm{~min}$, from $100 \% \mathrm{~A}$ to $30 \% \mathrm{~A}, 70 \% \mathrm{~B}$ with flow rate $1 \mathrm{~mL} / \mathrm{min}$; $40-45 \mathrm{~min}$, from $30 \% \mathrm{~A}$, $70 \%$ B to $20 \% \mathrm{~A}, 80 \%$ B with flow rate $1 \mathrm{~mL} / \mathrm{min}$; $45-$ $55 \mathrm{~min}$, from $20 \% \mathrm{~A}, 80 \% \mathrm{~B}$ to $15 \% \mathrm{~A}, 85 \% \mathrm{~B}$ with flow rate $1.2 \mathrm{~mL} / \mathrm{min}$; $55-57 \mathrm{~min}$, from $15 \% \mathrm{~A}, 85 \% \mathrm{~B}$ to $10 \% \mathrm{~A}, 90 \% \mathrm{~B}$ with flowrate $1.2 \mathrm{~mL} / \mathrm{min}$; and 57 $75 \mathrm{~min} \mathrm{10 \%} \mathrm{A,} \mathrm{90 \%} \mathrm{B} \mathrm{with} \mathrm{flow} \mathrm{rate} 1.2 \mathrm{~mL} / \mathrm{min}$. Operating conditions were as follows: column temperature, $30^{\circ} \mathrm{C}$, injection volume, $20 \mu \mathrm{L}$, UV-VIS photo diode array detection at $280 \mathrm{~nm}$. Detection was performed with UV-VIS photo diode array detector by scanning spectra from 210 to $360 \mathrm{~nm}$. Stock standard solutions at a concentration of $1 \mathrm{mg} \mathrm{ml}$, G1 were prepared in methanol/water (1:1) and stored at $4^{\circ} \mathrm{C}$ in darkness. Different range calibration curves for different polyphenol components in apricot samples were used.

\section{Analytical quality control}

Recoveries were measured by comparing retention times and spectral data with those of authentic standards. Quantitative determinations were carried out using calibration curves of the standards.

\section{Extraction and determination of vitamins}

Apricot samples $(50 \mathrm{~g})$ were mashed in a homogenizer and $4 \mathrm{~g}$ homogenate paste per sample were taken for extraction of vitamins $\mathrm{A}, \mathrm{E}, \beta$-carotene, lycopen and $1 \mathrm{~g}$ per sample was taken for extraction of vitamin C. To the above homogenates, $4 \mathrm{ml}$ of ethanol were added, vortexed and the mixture centrifuged (Mistral\#2000) at $2000 \mathrm{rpm}$ for $3 \mathrm{~min}$ at $4 \mathrm{~h}$. The supernatant was also filtered through a Whatman paper, and to the filtrate $0.15 \mathrm{ml} \mathrm{n}$-hexane was added and mixed. Vitamins A, E and $\beta$-carotene were extracted twice in the hexane phase and the collected extract was dried under a stream of liquid nitrogen. Dried extract was solubilized in $0.2 \mathrm{ml}$ methanol for HPLC. Injections were made in duplicate for each sample. The quantification [25] utilized absorption spectra of 326, 296 and $436 \mathrm{~nm}$ for vitamins A, E, and b-carotene, respectively.

HPLC separations were accomplished at room temperature consisting of a sample injection valve (Cotati 7125) with a $20 \mu \mathrm{l}$ sample loop, an ultraviolet (UV) spectrophotometric detector (and a Techsphere ODS-2 packed (5 mm particle and 80 A pore size) column (250_4.6 i.d.) with a methanol: acetonitrile: chloroform $(47: 42: 11, \mathrm{v} / \mathrm{v})$ mobile phase at $1 \mathrm{ml}$ per min flow rate. The extraction of vitamin $C$ was according to the method of Cerhata et al. [26]. To $1 \mathrm{~g}$ homogenized apricot paste, $1 \mathrm{ml}$ of $0.5 \mathrm{M}$ perchloric acid was added, vortexed and the volume adjusted to $5 \mathrm{ml}$ by adding ddH2O. The mixture was centrifuged at $5000 \mathrm{rpm}$ for $8 \mathrm{~min}$ at $4^{\circ} \mathrm{C}$, the supernatant was filtered, as earlier, and the vitamin $C$ level was determined using the method of Tavazzi et al. [27] by HPLC, utilizing a column (250_3.9 i.d.) packed with Tecopak C18 reversed-phase material $(10 \mathrm{~mm}$ particle size) with mobile phase (3.7 $\mathrm{mM}$ phosphate buffer, $\mathrm{pH} 4.0)$ at $1 \mathrm{ml}$ min 1 flow rate.

\section{Statistical analysis}

Experimental data were evaluated using analysis of variance (ANOVA) and significant differences among the means of three replicates $(p<0.05)$ were determined by Duncan's multiple range test, using the "SPSS 10.0 for Windows".

\section{Competing interests}

The authors declare that they do not have competing interests.

\section{Authors' contributions}

TK, MG, FM, FC, MKG, made a significant contribution to experiment design, acquisition of data, analysis and drafting of the manuscript. SE, OK and MZUH have made a substantial contribution to interpretation of data, drafting and carefully revising the manuscript for intellectual content. All authors read and approved the final manuscript.

\section{Author details}

${ }^{1}$ Agriculture Faculty, Horticulture Department, Inonu University, Malatya, Turkey. ${ }^{2}$ Agriculture Faculty, Biotechnology Department, Yuzuncu Yil University, Van, Turkey. ${ }^{3}$ Agriculture Faculty, Horticulture Department, Ataturk University, Erzurum, Turkey. ${ }^{4}$ Agriculture Faculty, Horticulture Department, Yuzuncu Yil University, Van, Turkey. ${ }^{5}$ Agriculture Faculty, Horticulture Department, Igdir University, Igdir, Turkey. ${ }^{6}$ Departement of Pomology, National School of Agriculture, Meknes, Morocco. ${ }^{7}$ The Patent Office Karachi, Karachi, Pakistan.

Received: 8 August 2014 Accepted: 15 September 2014 Published: 23 September 2014

\section{References}

1. Ercisli S: Apricot culture in Turkey. Sci Res Essays 2009, 4:715-719.

2. Hegedus A, Engel R, Abranko L, Balogh E, Blazovics A, Herman R, Halasz J, Ercisli S, Pedryc A, Stefanovits-Banyai E: Antioxidant and antiradical capacities in apricot (Prunus armeniaca L.) fruits: Variation from genotypes, years, and analytical methods. J Food Sci 2010, 75(9):C722-C730.

3. Hegedus A, Pfeiffer P, Papp N, Abranko L, Blazovics A, Pedryc A, Stefanovits-Banyai E: Accumulation of antioxidants in apricot fruit through 
ripening: characterization of a genotype with enhanced functional properties. Biol Res 2011, 44:339-344.

4. Femenia A, Rosello C, Mulet A, Canellas J: Chemical composition of bitter and sweet apricot kernels. J Agric Food Chem 1995, 43:356-361.

5. Radi M, Mahrouz M, Jaouad A: Phenolic content, browning susceptibility, and carotenoid content of several apricot cultivars at maturity. Hortic Sci 1997, 32:1087-1091.

6. Nout MJR, Tuncel G, Brimer L: Microbial degradation of amygdalin of bitter apricot seeds (Prunus armeniaca L.). Int J Food Microbiol 1995, 24:407-412.

7. Veberic R, Jakopic J, Stampar F, Schmitzer V: European elderberry (Sambucus nigra L.) rich in sugars, organic acids, anthocyanins and selected polyphenols. Food Chem 2009, 114:511-515.

8. Jurikova T, Rop O, Mlcek J, Sochor J, Balla S, Szekeres L, Hegedusova A, Hubalek J, Adam V, Kizek R: Phenolic profile of edible honeysuckle berries (Genus Lonicera) and their biological effects. Molecules 2012, 17:61-79.

9. Milivojevic J, Slatnar A, Mikulic-Petkovsek M, Stampar F, Nikolic M, Veberic R: The influence of early yield on the accumulation of major taste and health-related compounds in black and red currant cultivars (Ribes spp.). J Agric Food Chem 2012, 60:2682-2691.

10. Pfeiffer $P$, Hegedus $A$ : Review of the molecular genetics of flavonoid biosynthesis in fruits. Acta Aliment Hung 2011, 40:150-163.

11. Kim DO, Jeong SW, Lee CY: Antioxidant capacity of phenolic phytochemicals from various cultivars of plums. Food Chem 2003, 81:321-326.

12. Macheix JJ, Fleuriet A, Billot J: Fruit Phenolics. Boca Raton, FL: CRC Press; 1990:24-31. 295-342

13. Garcia-Viguera C, Zafrilla P, Tomas-Barberan FA: Determination of authenticity of fruit jams by HPLC analysis of anthocyanins. J Sci Food Agric 1997, 73:207-213.

14. Arts $C W$, van de Putte B, Hollman PCH: Catechin contents of foods commonly consumed in the Netherlands. 1. Fruits, vegetables, staple foods and processed foods. J Agric Food Chem 2000, 48:1746-1751.

15. Dragovic-Uzelac V, Pospisil J, Levaj B, Delonga K. The study of phenolic profiles of raw apricots and apples and their purees by HPLC for the evaluation of apricot nectars and jams authenticity. Food Chem 2005, 91:373-383.

16. Dragovic-Uzelac V, Delonga K, Levaj B, Djakovic S, Pospisil J: Phenolic profiles of raw apricots pumpkins and their purees in the evaluation of apricot nectars and jams authenticity. J Agric Food Chem 2005, 53:4836-4842.

17. Rice-Evans CA, Miller NJ, Paganga G: Antioxidant properties of phenolic compounds. Trends Plant Sci 1997, 2:152-159.

18. Vinson JA, Hao Y, Su X, Zubik L: Phenol antioxidant quantity and quality in foods:Vegetables. J Agric Food Chem 1998, 46:3630-3634.

19. Dragovic-Uzelac V, Levaj B, Mrkic V, Bursac D, Boras M: The content of polyphenols and carotenoids in three apricot cultivars depending on stage of maturity and geographical region. Food Chem 2007, 102:966-975.

20. Sultana B, Anwar F, Ashraf M, Saari N: Effect of drying techniques on the total phenolic contents and antioxidant activity of selected fruits. $J$ Med Plant Res 2012, 6:161-167.

21. Sochor J, Zitka O, Skutkova H, Pavlik D, Babula P, Krska B, Horna A, Adam V, Provaznik I, Kizek R: Content of phenolic compounds and antioxidant capacity in fruits of apricot genotypes. Molecules 2010, 15:6285-6305.

22. Rigal D, Gauillard F, Richard-Forget F: Changes in the carotenoid content of apricot (Prunus armeniaca, var Bergeron) during enzymatic browning: b-carotene inhibition of chlorogenic acid degradation. J Sci Food Agric 2000, 80:763-768.

23. Akin EB, Karabulut I, Topcu A: 2008. Some compositional properties of main Malatya apricot (Prunus armeniaca L.) varieties. Food Chem 2008, 107:939-948.

24. Bengoechea ML, Sancho AIB, Bartolomé IE, Gómez-Cordovés G: Phenolic composition of industrially manufactured purées and concentrates from peach and apple fruits. J Agric Food Chem 2007, 45:4071-4075.

25. Miller KW, Lorr NA, Yang CS: Simultaneous determination of plasma retinol a-tocopherol, lycopene, a-carotene, and b-carotene by high performance liquid chromatography. Anal Biochem 1984, 138:340-345.
26. Cerhata D, Bauerová A, Ginter E: Determination of ascorbic acid in blood serum using high performance liquid chromatography and its correlation with spectrophotometric (colorimetric) determination. Ceska Slov Farm 1994, 43:166-168.

27. Tavazzi B, Lazzarino G, Di-Pierro D, Giardina B: Malondialdehyde production and ascorbate decrease are associated to the eperfusion of the isolated postischemic rat heart. Free Rad Biol Med 1992, 13:75-78.

doi:10.1186/0717-6287-47-46

Cite this article as: Kan et al:: Phenolic compounds and vitamins in wild and cultivated apricot (Prunus armeniaca L.) fruits grown in irrigated and dry farming conditions. Biological Research 2014 47:46.

\section{Submit your next manuscript to BioMed Central and take full advantage of:}

- Convenient online submission

- Thorough peer review

- No space constraints or color figure charges

- Immediate publication on acceptance

- Inclusion in PubMed, CAS, Scopus and Google Scholar

- Research which is freely available for redistribution

Submit your manuscript at www.biomedcentral.com/submit
Ciomed Central 